\title{
Rise of the killer plants: investigating the antimicrobial activity of Australian plants to enhance biofilter-mediated pathogen removal
}

\author{
P. Galbraith ${ }^{*}$ (D, R. Henry and D. T. McCarthy
}

\begin{abstract}
Background: Biofilters are soil-plant based passive stormwater treatment systems which demonstrate promising, although inconsistent, removal of faecal microorganisms. Antimicrobial-producing plants represent a safe, inexpensive yet under-researched biofilter design component that may enhance treatment reliability. The mechanisms underlying plant-mediated microbial removal in biofilters have not been fully elucidated, particularly with respect to antimicrobial production. The aim of this study was therefore to inform biofilter vegetation selection guidelines for optimal pathogen treatment by conducting antimicrobial screening of biofilter-suitable plant species. This involved: (1) selecting native plants suitable for biofilters (17 species) in a Victorian context (southeast Australia); and (2) conducting antimicrobial susceptibility testing of selected plant methanolic extracts ( $\geq$ 5 biological replicates/species; 86 total) against reference stormwater faecal bacteria (Salmonella enterica subsp. enterica ser. Typhimurium, Enterococcus faecalis and Escherichia coli).

Results: The present study represents the first report on the inhibitory activity of polar alcoholic extracts from multiple tested species. Extracts of plants in the Myrtaceae family, reputed for their production of antimicrobial oils, demonstrated significantly lower minimum inhibitory concentrations (MICs) than non-myrtaceous candidates $(p<0$. 0001). Melaleuca fulgens (median MIC: $8 \mathrm{mg} / \mathrm{mL}$; range: [4-16 mg/mL]), Callistemon viminalis ( $16 \mathrm{mg} / \mathrm{mL}$, [2-16 mg/ $\mathrm{mL}]$ ) and Leptospermum lanigerum $(8 \mathrm{mg} / \mathrm{mL},[4-16 \mathrm{mg} / \mathrm{mL}])$ exhibited the strongest inhibitory activity against the selected bacteria ( $p<0.05$ compared to each tested non-myrtaceous candidate). In contrast, the Australian biofilter gold standard Carex appressa demonstrated eight-fold lower activity than the highest performer M. fulgens (64 mg/ $\mathrm{mL}$, [32-64 mg/mL]).

Conclusion: Our results suggest that myrtaceous plants, particularly M. fulgens, may be more effective than the current vegetation gold standard in mediating antibiosis and thus improving pathogen treatment within biofilters. Further investigation of these plants in biofilter contexts is recommended to refine biofilter vegetation selection guidelines.
\end{abstract}

Keywords: Antimicrobial, Vegetation, Urban stormwater, Biofilter, Fecal microorganisms, Pathogens, WSUD

\footnotetext{
* Correspondence: Penelope.Galbraith@monash.edu

Environmental and Public Health Microbiology Laboratory (EPHM Lab),

Monash Water for Liveability, Department of Civil Engineering, Monash

University, Wellington Road, Clayton, Victoria 3800, Australia
}

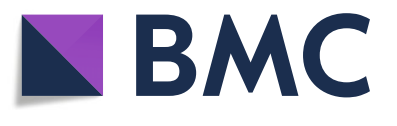

(c) The Author(s). 2019 Open Access This article is distributed under the terms of the Creative Commons Attribution 4.0 International License (http://creativecommons.org/licenses/by/4.0/), which permits unrestricted use, distribution, and reproduction in any medium, provided you give appropriate credit to the original author(s) and the source, provide a link to the Creative Commons license, and indicate if changes were made. The Creative Commons Public Domain Dedication waiver (http://creativecommons.org/publicdomain/zero/1.0/) applies to the data made available in this article, unless otherwise stated. 


\section{Background}

Freshwater scarcity represents a cumulative environmental and humanitarian challenge [1]. With increasing pressures on natural water resources from irresponsible waste disposal, changing land use patterns, climate change and population growth [2], stormwater has gained recognition as an important alternative freshwater resource. Prior to reuse, stormwater must undergo treatment to remove pollutants of concern to human health. The most significant of these are disease-causing faecal microorganisms (faecal pathogens) [3].

A diverse range of faecal pathogens originating from varied sources, including viruses, bacteria and protozoa, can be present in stormwater. Limited studies suggest that pathogen concentrations in stormwater are highly variable, ranging from $8.0 \times 10^{-2}$ to $1.9 \times 10^{6}$ organisms per litre depending on specific microbial (species, physiology) and environmental (land use, climate and hydrology) factors [4-6]. Some pathogens may be present in stormwater at sufficient concentrations to cause disease, particularly those with low infectious doses. For example, E. coli O157:H7 (notable haemorrhagic colitisassociated enteropathogen; infectious dose of 1-10 organisms [7]), has been detected in stormwater at levels posing significant disease risk to exposed individuals (up to $1.3 \times 10^{6}$ organisms per litre) [8]. Removal of faecal microorganisms from stormwater is therefore a priority to alleviate health risks associated with downstream harvesting and recreational use.

A range of water sensitive urban design (WSUD) technologies have emerged to facilitate stormwater pollutant removal under a holistic water conservation approach; among these are stormwater biofilters [9]. Biofilters are low-cost, soil-plant based WSUD stormwater treatment systems that demonstrate effective removal of multiple pollutants [10]. When designed according to best practise, these systems can achieve effective reductions in suspended solids ( $>95 \%$ removal), nitrogen $(>50 \%)$, phosphorous $(>65 \%)$ and heavy metals (except for $\mathrm{Al}$; > 90\%) from stormwater [10-12]. Biofilters have moreover demonstrated promising reductions in faecal microorganism concentrations in stormwater. Three- to four-log removal rates of the common faecal indicator organism (FIO) E. coli have been reported in biofilters of varying design [13-16]. Nevertheless, significant differences in removal performance have also been reported in literature $[14,16-18]$, with certain operational conditions causing removal rates to decline from $>90 \%$ to net export within the same system $[19,20]$.

Microorganism removal performance can decline when intervals between rainfall periods are too short (i.e. back-to-back storm events) or too long (i.e. $>2$ weeks), particularly when influent contains high microbial loads [18]. Performance also varies over biofilter lifespan owing to changes in microbial retention (straining and adsorption) with ongoing hydraulic compaction and sediment accumulation on the biofilter surface [14]. Due to their ongoing variability in removal performance, biofilters do not consistently meet removal targets for stormwater recycling (other than some irrigation purposes) [5, 16]. Consequently, additional disinfection steps are generally required prior to reuse of biofilter-treated stormwater (e.g. chlorination, UV irradiation). Removal inconsistency during the course of biofilter operation represents an impediment to the uptake of these systems by urban water managers [21].

To seek opportunities for improving pathogen removal consistency, research has focused on biofilter design. The majority of this work has been conducted on enhancing microbial retention within biofilters, such as through inclusion of a saturated/submerged zone (SZ) [22] and adsorption-promoting filter media [23-25]. More recently, researchers have attempted to enhance in-situ pathogen inactivation processes through the addition of antimicrobial filter media [21, 26-28]. Results have demonstrated that some configurations were capable of achieving consistent 2-log reductions in $E$. coli within the first $40 \mathrm{~min}$ of infiltration [26]. While antimicrobial media offer an excellent opportunity for improved pathogen inactivation, many require further optimisation to decrease costs, remove true pathogens (not solely FIOs), maintain performance during operation (especially with cold temperatures and clogged conditions) [21], or resolve leaching of antimicrobial amendments into effluent $[26,28]$. To complement research into advancing filter media for microbial removal, other biofilter design elements are undergoing further investigation.

One crucial biofilter design feature affecting pathogen removal is vegetation. Plants represent a safe, inexpensive and easily adaptable biofilter component with established efficacy in facilitating the removal of multiple stormwater pollutants, particularly nutrients and metals [29]. Plants directly assimilate dissolved pollutants, while their roots provide solid surfaces on which biofilms form and adsorb colloidal and suspended sediment-bound pollutants [30,31]. Preliminary research indicates that plants also play a significant role in faecal microorganism removal within biofilters [22]. For example, systems vegetated with plants possessing extensive root systems have demonstrated the greatest $E$. coli removal from stormwater, potentially due to increased root surface area corresponding with enhanced microbial retention [22, 32, 33]. Plants may also modulate physicochemical parameters within biofilters including UV penetration, soil $\mathrm{pH}$, and concentrations of nutrients, oxygen and carbon dioxide [34-36] depending on plant life stage, genetics and various biotic and abiotic stresses. Although 
the role of plants in pollutant removal within biofilters has been well-established, the mechanisms by which they govern pathogen removal remain poorly characterised.

Perhaps most importantly, some plants possess antimicrobial properties which may aid in pathogen removal within biofilters. Previous studies have noted that multiple plant species employed in WSUD systems produce antimicrobial compounds [37-41]. In particular, native Australian plants represent a trove of hardy, antimicrobial-producing candidates that may significantly improve pathogen die-off in biofilters. Two Australian plants known for their antimicrobial properties, Melaleuca incana and Leptospermum continentale, were observed to achieve 10-fold higher E. coli reductions in biofilters than other planted systems with similar retention (infiltration) rates [22]. It was hypothesised that the introduction of antimicrobial compounds by these plants augmented pathogen die-off in these systems $[22,42]$ via litterfall and/or root secretions [42, 43]. A subsequent $E$. coli survival test conducted on root exudate solutions from harvested plants confirmed that $L$. continentale exhibited higher antimicrobial activity than Carex appressa [42]. This finding was reinforced by Shirdashtzadeh et al. [43], who conducted antimicrobial screening of seedlings (extracts) and seeds (exudates and extracts) from nine biofilter-suitable plants against E. coli. Melaleuca ericifolia, a close relative of $M$. incana, demonstrated the greatest observed inhibitory activity of tested species. In combination, these findings suggest that incorporating highly antimicrobial plants into plant selection guidelines for biofilters may enhance pathogen die-off within these systems.

The leaves, seeds and flowers of a variety of native Australian plants employed in biofilters, including Allocasuarina sp., Acacia sp., Melaleuca sp. and Leptospermum sp., are known to contain antimicrobial compounds such as terpenes, triketones and phenols [44-47]. Tissue extracts from these and other Australian native plants often demonstrate strong antimicrobial activity against faecal pathogens $[44,45,48-50]$. It is predicted that a proportion of plant antimicrobials deposited into biofilters originates from litterfall. Antimicrobial compounds may be released from decomposing litter into the top media layers of biofilters, where most faecal bacteria are retained [51, 52]. Antimicrobial compounds in litterfall may interfere with microbial nutritional processes (e.g. decomposition, mineralisation, and humification) and survival [53], potentially resulting in increased die-off of exposed microorganisms at the biofilter surface (via litter accumulation) and subsurface (via aqueous leachates and litter bioturbation). Antimicrobial quality and quantity in litterfall can vary depending on intrinsic plant factors (e.g. species/genotype, age, health, biomass), environmental physicochemical factors (e.g. UV intensity, altitude, temperature, moisture availability, salinity, nutrients, $\mathrm{pH}$ ), and the soil microbial population (abundance of plant pathogens and commensals/mutualists) [54-59]. Litter deposition rates are also influenced by prevailing environmental conditions, with many south-eastern Australian plants depositing larger litter volumes in summer [60]. In this way, environmental modulation of antimicrobial deposition via litterfall may affect pathogen treatment within biofilters.

In addition to litter inputs, plants may release antimicrobial compounds into biofilters via root exudates. Some native biofilter-suitable Acacia and Callistemon species are known to produce root exudates containing inhibitory compounds [61-63]. For example, Leptospermone, a $\beta$-triketone with broad-spectrum antibacterial [64] and allelopathic activity, is produced by Callistemon $s p$. (Myrtaceae) roots to suppress weeds around the plant's base [63]. Prosser et al. [65] suggested that rhizodeposition of this and other antimicrobial compounds potentially enhanced the observed removal of $E$. coli in soil vegetated with related species (Leptospermum and Kunzea sp., family Myrtaceae). Furthermore, Chandrasena et al. [22] suggested that antimicrobial root exudates contributed to improved pathogen removal in biofilters planted with myrtaceous Leptospermum and Melaleuca species. Nevertheless, the influence of root exudates on biofilter-mediated pathogen removal remains uncharacterised.

Antimicrobial vegetation represents an under-investigated biofilter design feature which may have significant pathogen inactivation potential [22]. Some independent antimicrobial susceptibility testing (AST) assays have been conducted on the exudates and tissue extracts of certain plant species that have been employed in biofilters [44-47]. However, only a single study to date has conducted antimicrobial testing on plants selected for their specific suitability in biofilters (seed exudates, seed and seedling extracts) against a single stormwater faecal microorganism (E. coli) [43]. The antimicrobial effect of mature plants selected for their specific suitability in biofilters against stormwater pathogens remains yet to be investigated. Furthermore, the antimicrobial effect of leaf litter in biofilters remains uncharacterised, despite being a potential facilitator of pathogen treatment in these systems.

The aim of this study was therefore to conduct antimicrobial screening of suitable mature Australian plants to inform biofilter vegetation selection guidelines for optimal pathogen removal. The following objectives were applied to meet this aim: (1) selecting appropriate native plant candidates for survival and function in biofilters in a Victorian context (south-eastern Australia); and (2) conducting antimicrobial susceptibility testing (AST) of 
selected plants against multiple reference stormwater faecal bacteria (Salmonella enterica subsp. enterica ser. Typhimurium, Enterococcus faecalis and Escherichia coli). This study elucidates several antimicrobial plant species with specific suitability in biofilters that demonstrate noteworthy potential for enhancing pathogen treatment in these systems. The findings of this study represent an important contribution to the development of best-practise vegetation selection guidelines, and underpin prospective research into the role of vegetation in microorganism removal within WSUD systems.

\section{Methods}

\section{Plant selection}

Plant species from sedge, shrub and tree retail stock lists of nine major native plant nurseries in Melbourne (Victoria, Australia) were combined for preliminary screening. Selection from native nurseries ensured that candidates fulfilled the following criteria: 1 ) native to Australia; 2 ) easily accessible to stakeholders for purchase and implementation in biofilters; and 3) unlikely to become invasive weeds once established. Native Australian plants were preferentially examined owing to many possessing adaptations that confer inherent suitability to biofilter environments (e.g. resistance to drought, high temperatures, high UV intensity, poorly structured soils with low organic matter/limited nutrients, and in some cases, heavy metal exposure) $[66,67]$. Each species in the combined list of plants was manually ranked with consideration to multiple weighted criteria (Table 1). These criteria included adaptation to common biofilter conditions (i.e. drought-tolerance, ability to grow in sandy soil, ability to withstand periodic temporary inundation), possession of deep, extensive root systems (previously associated with effective removal of pathogens and other pollutants [22, 29, 68], lack of nitrogen fixing capability (linked to poor $\mathrm{N}$ removal [69]), high growth rate (associated with optimal nutrient removal $[29,70])$, and suitable sizing for integration into most streetscape biofilter systems $(<10 \mathrm{~m}$ in height) (Table 1). Plant species were subsequently assigned an "antimicrobial score" based on literature searches to provide an indication of known antimicrobial activity (Additional file 1: Table S1 description). Species demonstrating very low $(<1)$ or high $(>30)$ antimicrobial scores were considered for selection as "putatively antimicrobial" and "putatively non-antimicrobial" test plants, respectively. Taking all the above criteria and their relative weightings into account, species ranks $(0-5)$ were assigned to each plant. Detailed steps on calculating species ranks are outlined in Additional file 1: Table S1 footnotes.

\section{Sample collection}

Fresh leaf samples were collected from healthy, mature individuals (aged $\sim 3-\sim 70$ years old) of species with overall ranks of $\geq 3$ around metropolitan greater
Melbourne (29/09/16-17/11/16, spring). Sampling was conducted in botanical gardens, parkland, nature strips and nature reserves of 30 geographically distinct areas, ensuring accurate statistical representation of antimicrobial production variation with exposure to different biotic and abiotic conditions. Species identities of samples were confirmed through expert opinion (horticulturalists, botanists and botanical garden curators) in conjunction with the use of taxonomic keys [76, 77]. Healthy leaves from multiple locations of the canopy $(\sim 5 \mathrm{~g})$ were collected from each individual to ensure representative foliage sampling. Samples were transported on ice to the laboratory within $5 \mathrm{~h}$ of collection and stored at $-80^{\circ} \mathrm{C}$ prior to processing.

\section{Sample processing and extract preparation}

Methanolic extracts were prepared from leaf samples for species with $>5$ individuals sampled. The method of Wright et al. [78] was applied, with modification. Briefly, leaf samples were thawed, ground coarsely and freeze-dried over $72 \mathrm{~h}$. Subsamples $(0.5-2.5 \mathrm{~g})$ of each dried sample were crushed finely and extracted in $50 \mathrm{~mL}$ pure methanol (EMSURE ${ }^{\circ}$ ACS grade, Merck Millipore, Germany) with gentle rotation at $60-80 \mathrm{rpm}$ over $24 \mathrm{~h}$ at $25 \pm 2{ }^{\circ} \mathrm{C}$. The extract was centrifuged at $3153 \mathrm{rpm}$ $(2000 x g)$ for $5 \mathrm{~min}$ and the supernatant collected [45]. Aliquots ( $25 \mathrm{~mL}$ in two separate volumes) of each methanolic extract were open-air evaporated over $24 \mathrm{~h}$ under a fume hood [79]. Tubes were then weighed to determine extraction efficiency and stored at $-80^{\circ} \mathrm{C}$. The extracted plant material was subsequently resuspended and homogenised in 1\% DMSO (Sigma-Aldrich, USA) in deionised water $(0.4-1.2 \mathrm{~mL}$ volumes) to achieve final concentrations of $>128 \mathrm{mg} / \mathrm{mL}$ (at least double $64 \mathrm{mg} /$ $\mathrm{mL}$, the starting concentration for subsequent antimicrobial testing). All resuspended extracts were transferred into new storage vessels, with the final concentrations $(\mathrm{mg} / \mathrm{mL})$ calculated by subtracting the weight of any fine material remaining in the original vessel. Resuspended extracts were stored at $-80^{\circ} \mathrm{C}$ prior to further processing.

\section{Reference strains and standardisation of inoculum}

Salmonella enterica subsp. enterica ser. Typhimurium TM11 (SARA12) (Gram-negative faecal pathogen; abbreviated to Salmonella ser. Typhimurium hereafter) [80], Escherichia coli ATCC 11775 (Gram-negative FIO) [81, 82] and Enterococcus faecalis ATCC 29212 (Gram-positive FIO) [83] were selected as the test organisms for all antimicrobial susceptibility testing (AST) assays. Each reference strain was subcultured by streaking onto Brain Heart Infusion (BHI) agar (Oxoid, UK) from stock solution stored at $-80^{\circ} \mathrm{C}$. BHI plates were incubated at $37^{\circ} \mathrm{C}$ for $18 \pm 2 \mathrm{~h}$. Inoculum standardisation for each 
Table 1 Weighted criteria for selecting test plant species based on suitability in field-scale biofilters and known antimicrobial production

\begin{tabular}{|c|c|c|c|}
\hline $\begin{array}{l}\text { Selection } \\
\text { criteria }\end{array}$ & Description & Reference & Weighting of importance \\
\hline \multicolumn{4}{|c|}{ Primary considerations for species selection } \\
\hline \multirow{2}{*}{$\begin{array}{l}\text { Availability in } \\
\text { nurseries }\end{array}$} & \multirow[t]{2}{*}{ Available from $\geq 1$ of 9 major native nurseries in Melbourne. } & \multirow[t]{2}{*}[29]{} & $\checkmark \checkmark \checkmark \checkmark \checkmark$ \\
\hline & & & Accessible to stakeholders for purchase \\
\hline \multirow{2}{*}{$\begin{array}{l}\text { Adaptation to } \\
\text { biofilter } \\
\text { conditions }\end{array}$} & \multirow{2}{*}{$\begin{array}{l}\text { Species were scored (1-3) based on their ability to maintain healthy growth under } \\
\text { south-eastern Australian biofilter conditions (i.e. survival in sandy soil with tempor- } \\
\text { ary inundation and extended hot, dry periods). Plants with scores of } \geq 2 \text { were con- } \\
\text { sidered for selection. }\end{array}$} & \multirow[t]{2}{*}[11,68]{} & $\checkmark \checkmark \checkmark \checkmark \checkmark$ \\
\hline & & & $\begin{array}{l}\text { Plants must be adapted to harsh conditions in } \\
\text { biofilters for effective performance }\end{array}$ \\
\hline \multirow{2}{*}{$\begin{array}{l}\text { Antimicrobial } \\
\text { activity of plants }\end{array}$} & \multirow{2}{*}{$\begin{array}{l}\text { Species were assigned an antimicrobial score based on the number of positive } \\
\text { Google Scholar search results associating plant genus with antimicrobial-associated } \\
\text { terms*. Species with an antimicrobial score of }>30 \text { and }<1 \text { were considered for } \\
\text { selection. }\end{array}$} & \multirow[t]{2}{*}{ [43] } & $\checkmark \checkmark \checkmark \checkmark \checkmark$ \\
\hline & & & Parameter essential to answer key objectives of study \\
\hline \multirow{2}{*}{$\begin{array}{l}\text { Extensive root } \\
\text { system }\end{array}$} & \multirow{2}{*}{$\begin{array}{l}\text { Species were scored (1, } 2 \text { or } 3 \text { ) based on root structure characteristics, with } 3 \\
\text { representing "very good" (deep, dense, extensive, fine roots), } 2 \text { representing } \\
\text { "average" and } 3 \text { representing "poor" roots (shallow, thick, minimal root systems). } \\
\text { Candidates with scores } \geq 2 \text { were considered for selection. }\end{array}$} & \multirow{2}{*}{$\begin{array}{l}{[22,29,} \\
68]\end{array}$} & $\checkmark \checkmark \checkmark \checkmark \checkmark$ \\
\hline & & & $\begin{array}{l}\text { Extensive root systems correspond with high } \\
\text { pollutant and faecal microorganism removal }\end{array}$ \\
\hline \multirow[t]{2}{*}{ Invasive species } & \multirow{2}{*}{$\begin{array}{l}\text { Species deemed to have a high risk of becoming invasive, even if native to } \\
\text { Australia, were excluded from selection. }\end{array}$} & \multirow[t]{2}{*}{ [29] } & $\checkmark \checkmark \checkmark \checkmark \checkmark$ \\
\hline & & & $\begin{array}{l}\text { Necessary to avoid ecological damage to surrounding } \\
\text { ecosystems in field applications }\end{array}$ \\
\hline \multirow[t]{2}{*}{ Plant size } & \multirow{2}{*}{$\begin{array}{l}\text { Species typically growing } \leq 10 \mathrm{~m} \text { in height and } \geq 1 \mathrm{~m} \text { in canopy diameter (sedges } \\
\text { excepted) were considered for selection. Tall trees are generally impractical or } \\
\text { unpopular in streetscape biofilters, while slender shrubs/trees with sparse above- } \\
\text { ground biomass have diminished treatment capacity [71] due to their generally } \\
\text { lower litterfall and weaker root systems [68]. }\end{array}$} & \multirow[t]{2}{*}[29,68]{} & $\checkmark \checkmark \checkmark \checkmark \checkmark$ \\
\hline & & & $\begin{array}{l}\text { Size constraints necessary for successful field } \\
\text { application }\end{array}$ \\
\hline \multicolumn{4}{|c|}{ Secondary considerations for species selection } \\
\hline \multirow{2}{*}{$\begin{array}{l}\text { Woody plants } \\
\text { (shrubs and } \\
\text { trees) }\end{array}$} & \multirow{2}{*}{$\begin{array}{l}\text { Woody species were preferentially selected. Compared with herbaceous species, } \\
\text { woody species tend to live longer, root more extensively, grow taller and produce } \\
\text { more biomass and leaf litter for improved treatment capacity }[72,73] \text {. }\end{array}$} & \multirow{2}{*}{$\begin{array}{l}{[68,72,} \\
73]\end{array}$} & $\checkmark \checkmark \checkmark$ \\
\hline & & & $\begin{array}{l}\text { Woody plants have associations with multiple criteria } \\
\text { that improve suitability and performance in biofilters }\end{array}$ \\
\hline \multirow{2}{*}{$\begin{array}{l}\text { Indigenous to } \\
\text { Melbourne }\end{array}$} & \multirow{2}{*}{$\begin{array}{l}\text { Species indigenous to Melbourne were preferentially selected over other Australian } \\
\text { natives. Indigenous species are likely to have superior survival rates and provide } \\
\text { greater ecological benefits over non-native species. Indigenous plants are also less } \\
\text { likely to become invasive or cause environmental harm. }\end{array}$} & \multirow[t]{2}{*}[29,68]{} & $\checkmark \checkmark \checkmark$ \\
\hline & & & $\begin{array}{l}\text { Plants indigenous to Melbourne are preferred, } \\
\text { although other Australian natives are suitable } \\
\text { depending on biofilter location and treatment } \\
\text { context }\end{array}$ \\
\hline \multirow{2}{*}{$\begin{array}{l}\text { High past } \\
\text { success in } \\
\text { biofilters }\end{array}$} & \multirow[t]{2}{*}{ Species with high past performance in biofilters were preferentially selected. } & \multirow{2}{*}{$\begin{array}{l}{[11,29,} \\
68]\end{array}$} & $\checkmark \checkmark \checkmark$ \\
\hline & & & $\begin{array}{l}\text { Multiple pollutant removal for enhanced field } \\
\text { application performance }\end{array}$ \\
\hline \multirow{2}{*}{$\begin{array}{l}\text { High growth } \\
\text { rate }\end{array}$} & \multirow{2}{*}{$\begin{array}{l}\text { Species with high growth rates were preferentially selected due to associations } \\
\text { with improved nutrient removal. }\end{array}$} & \multirow[t]{2}{*}[29,68]{} & $\checkmark \checkmark$ \\
\hline & & & $\begin{array}{l}\text { Multiple pollutant removal for enhanced field } \\
\text { application performance }\end{array}$ \\
\hline \multirow{2}{*}{$\begin{array}{l}\text { Nitrogen } \\
\text { fixation }\end{array}$} & \multirow{2}{*}{$\begin{array}{l}\text { Species lacking nitrogen-fixing root systems were preferentially selected to avoid } \\
\text { compromised nitrogen removal. }\end{array}$} & {$[29,70]$} & $\checkmark \checkmark$ \\
\hline & & & $\begin{array}{l}\text { Multiple pollutant removal for enhanced field } \\
\text { application performance }\end{array}$ \\
\hline Lifespan & Plants with lifespans $>20$ years were preferentially selected over shorter-lived spe- & {$[74]$} & $\checkmark \checkmark$ \\
\hline & & & $\begin{array}{l}\text { Reduced maintenance costs and disturbance to } \\
\text { biofilter function }\end{array}$ \\
\hline
\end{tabular}

The weighted/relative importance of each plant selection criterion (right-most column) was denoted by a number of ticks ( $\checkmark$ ), with five ticks indicating "very high importance", four ticks "high importance", three ticks "moderate importance" and two ticks "relatively low importance"

*Details on antimicrobial score assignment are outlined in Table S.1 description. Secondary metabolite publications were incorporated in the overall antimicrobial score for each plant species, owing to secondary metabolite production providing an indication of antimicrobial activity in plants where antimicrobial testing has not yet been conducted [75]. A Spearman correlation rank of $0.86(p<0.0001)$ indicates there is a strong correlation between "Antimicrobial" and "Secondary metabolite" Google Scholar publication count for each filtered species (as determined by GraphPad Prism version 7, GraphPad Software, USA)

organism was carried out using the colony suspension method to ensure reproducible AST results [83]. Briefly, 3-5 colonies were selected from BHI plates and inoculated into BHI broth. Multiple dilutions of the culture were prepared with optical densities (OD) ranging from $0.01-0.13$ at $625 \mathrm{~nm}$ [83] as determined by spectrophotometry (DR 5000, Hach spectrophotometer) [84] and quantified (colony forming units $/ \mathrm{mL}$ i.e. $\mathrm{CFU} / \mathrm{mL}$ ) by standard colony counting procedures. Calibration curves were plotted (cell concentration vs. OD at each dilution) to determine the absorbance at which a cell density of $5 \pm$ $3 \times 10^{5} \mathrm{CFU} / \mathrm{mL}$ could be achieved, as per CLSI [83] and Sutton [84]. 


\section{Antimicrobial susceptibility testing of methanolic plant extracts.}

Antimicrobial susceptibility testing of methanolic plant extracts ( $n=86,17$ species) was conducted following the standardised Clinical Laboratory Standard Institute (CLSI) broth microdilution broth assay [83]. Similarly to Kurekci et al. [45], plant extracts were thawed and examined for microbial contamination by streaking onto $\mathrm{BHI}$ and incubating at $35^{\circ} \mathrm{C}$ over $24 \mathrm{~h}$. Extracts were centrifuged briefly at $3153 \mathrm{rpm}(2000 x g)$ to remove strongly coloured particulates from suspension. The supernatant was diluted in sterile Mueller-Hinton broth (MHB) (Oxoid, UK) to a starting concentration of 64 $\mathrm{mg} / \mathrm{mL}$ in the initial wells of a 96-well microplate (clear flat bottom TC-treated; Falcon, USA). Two-fold serial dilutions of the initial $64 \mathrm{mg} / \mathrm{mL}$ wells were then prepared in horizontal wells (left to right) with $\mathrm{MHB}$, down to a final concentration of $125 \mu \mathrm{g} / \mathrm{mL}$ (final well volumes $100 \mu \mathrm{L})$. All samples were prepared in at least duplicate for each test concentration.

Salmonella ser. Typhimurium, E. coli and E. faecalis BHI broth cultures were prepared as described above (see Reference strains and standardisation of inoculum) to a final inoculum concentration of $5 \times 10^{5} \mathrm{CFU} / \mathrm{mL}$. All wells were inoculated with $5 \mu \mathrm{L}$ of test organism ( $2.5 \times 10^{3} \mathrm{CFU}$ per well). Inocula concentrations were confirmed by viable plate counts on BHI agar (appropriate range: $5 \pm 3 \times 10^{5} \mathrm{CFU} / \mathrm{mL}$ ). Wells containing a negative antimicrobial control (MHB containing 1\% DMSO, i.e. the concentration of DMSO in extracts) and a positive antimicrobial control (MHB containing $50 \mu \mathrm{g} / \mathrm{mL}$ gentamicin, Sigma-Aldrich, USA) were prepared in duplicate for comparison. Microplates were sealed and incubated at $35^{\circ} \mathrm{C}$ for $18 \mathrm{~h}$ under aerobic conditions. To indicate microbial respiratory activity, the colorimetric growth indicator INT (2-p-iodophenyl-3-p-nitrophenyl-5-phenyl tetrazolium chloride, Sigma-Aldrich, USA) dissolved in water $(2 \mathrm{mg} / \mathrm{mL})$ was added to each well in $10 \mu \mathrm{L}$ volumes before incubating microplates for a further $30 \mathrm{~min}$ in the dark [85, 86]. Active bacterial growth was indicated by a visible change from colourless to purple-pink, based on the reduction of INT (colourless) to INT-formazan (purple-pink). The lowest extract concentration demonstrating the absence of a colour change was taken as the minimum inhibitory concentration (MIC) $[85,86]$.

\section{Statistics}

Statistical comparisons were conducted using uncorrected Mann-Whitney (MW) tests (nonparametric 2-group comparisons) and Dunn's corrected Kruskal-Wallis (DKW) tests (nonparametric $>2$ group comparisons). A DKW test was applied to compare each individual plant species (combined test organism MIC data), and comparisons that were significant $(<0.05 ; n=$ 40 comparisons) were confirmed by post hoc Bonferroni-corrected Mann-Whitney (PBMW) tests [87, 88]. For all significant DKW tests, PBMW tests generated identical outcomes of significance at an alpha level of 0.05. Spearman correlation tests were applied for correlation analyses. All statistical analyses were performed using GraphPad Prism version 7 (GraphPad Software, USA).

\section{Results and discussion \\ Classification of plants}

Of the list of 333 plant species compiled from Melbourne nurseries, 42 achieved overall species ranks of $\geq 3$. In order to inform biofilter vegetation design guidelines for optimal microbial removal, species were categorised based on whether they demonstrated high (>30) or low $(<1)$ antimicrobial scores. These were tentatively associated with stronger and weaker potentials for mediating antibiosis against faecal microorganisms within biofilters, respectively. All species demonstrating high antimicrobial scores ( $n=11$ species) belonged to the family Myrtaceae (tested genera: Callistemon, Leptospermum and Melaleuca), a family comprising species recognised for their significant production of antimicrobial oils [50, 65, 89] (listed in Fig. 1). These species were applied as "putatively antimicrobial" test plants. The remaining species $(n=6)$ were represented by a range of non-myrtaceous genera (Philotheca myoporoides, Bursaria spinosa subsp. spinosa, Goodenia ovata, Westringia fruticosa and Carex appressa). All of these lacked previous recognition of significant antimicrobial activity against human-derived microorganisms (antimicrobial scores $\leq 0.5$; Additional file 1: Table S1). Accordingly, these were applied as "putatively non-antimicrobial" plants. Each selected species was sampled from diverse urban environments to account for the varying influences of intrinsic (e.g. genetic, plant life stage) and environmental (e.g. climate) factors on antimicrobial production. A total of 86 samples were collected ( $\geq 5$ individuals per species). All selected species, their individual characteristics and scoring are described in Additional file 1: Table S1; GPS locations of all tested individuals are specified in Additional file 1: Tables S2 and Table S3.

\section{Antimicrobial susceptibility testing}

Samples from selected species $(n=86$ total) underwent processing for antimicrobial susceptibility testing (AST) against the selected reference organisms E. coli, Salmonella ser. Typhimurium and E. faecalis. The broth microdilution method was employed due to it being recognised as one of the most reproducible, economical, rapid and commonly employed methods for quantitative determination 


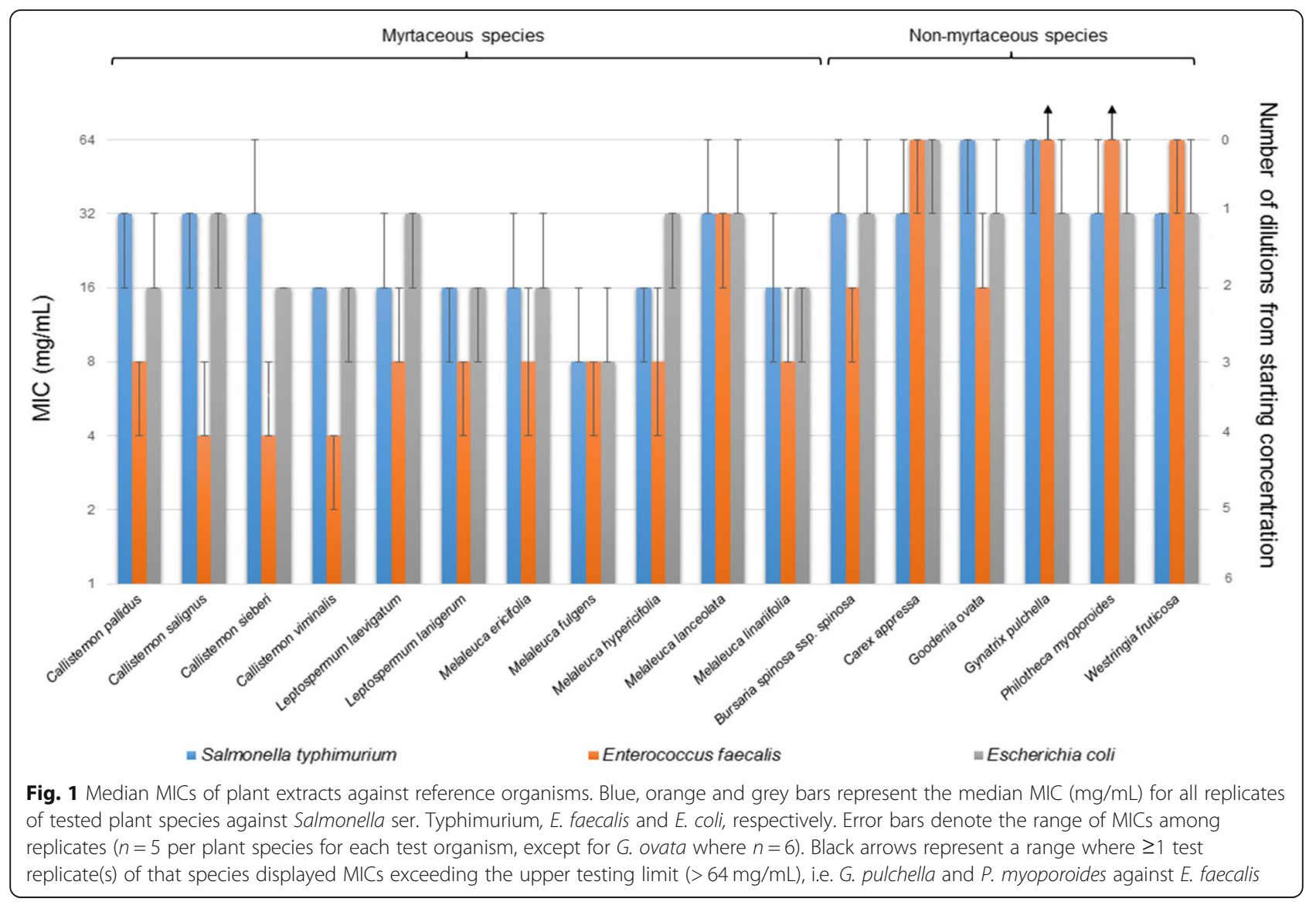

of plant antimicrobial activity [85, 90, 91]. Prior to testing, all extracts were confirmed free of culturable contaminant organisms, and to contain sufficient amounts of material allowing for resuspension at a starting concentration of $64 \mathrm{mg} / \mathrm{mL}$. Consistent with previous observations, all $1 \%$ DMSO growth control wells ( $n=2$ per tray; 50 total) exhibited positive growth of all test organisms [45] indicating DMSO's lack of inhibitory activity at $1 \%$ concentration. Furthermore, all $50 \mu \mathrm{g} / \mathrm{mL}$ gentamicin growth inhibition controls ( $\mathrm{n}=2$ per tray; 50 total) demonstrated negative growth for all test organisms.

\section{Variability in antimicrobial activities between plant species}

Resuspended methanolic extracts of all plants demonstrated MICs ranging from 2 to $>64 \mathrm{mg} / \mathrm{mL}$ (median: $16 \mathrm{mg} / \mathrm{mL}$ ) against all three test organisms (Fig. 1. Median MICs and ranges for all test species are listed in Additional file 1: Table S2; individual sample MICs are tabulated in Additional file 1: Tables S3 and Table S4. Observed median MICs of tested plant extracts correlated with their Google Scholar literature-based antimicrobial scores (Table 1 \& Additional file 1: Table S1; Spearman $r=0.622$; Spearman's rank test), validating this method as a quick and easy means of screening for plant species' antimicrobial potential.

Collectively, extracts of the "putatively antimicrobial" myrtaceous test plants demonstrated higher inhibitory activity against all tested organisms (median: $16 \mathrm{mg} / \mathrm{mL}$, range: [2-64 $\mathrm{mg} / \mathrm{mL}$ ]) in comparison to the "putatively non-antimicrobial" non-myrtaceous counterparts (32 $\mathrm{mg} / \mathrm{mL},[8->64 \mathrm{mg} / \mathrm{mL}$ ]; $p<0.0001$, uncorrected MW test). Significant variation was also observed between individual species $(\mathrm{p}<0.0001$, DKW test; all significant between-species comparisons are listed in Additional file 1: Table S5) (Fig. 1). All individual myrtaceous species, except for $M$. lanceolata, demonstrated greater inhibitory activity than the three lowest performing non-myrtaceous species $(p<0.05$ for all DKW and PBMW comparisons), namely G. pulchella, P. myoporoides (both $64 \mathrm{mg} / \mathrm{mL},[32->64 \mathrm{mg} / \mathrm{mL}]$ ) and $C$. appressa $(64 \mathrm{mg} / \mathrm{mL},[32-64 \mathrm{mg} / \mathrm{mL}])$.

The three myrtaceous genera comprising "putatively antimicrobial" test plants, namely Callistemon, Leptospermum and Melaleuca, are well-recognised for their production of antimicrobial essential oils [92, 93]. Thus far, researchers have predominantly investigated essential oils and non-polar extracts in Australian plant AST studies [94]. The antimicrobial activity of polar extracts 
derived from these and other Australian plants remains considerably less explored, despite significant activity having been reported in existing studies [94, 95]. Extract solvent choice plays an important role in evaluating plant antimicrobial activity, owing to variation in solubility of different active compounds between solvents. Methanol is one of the most commonly employed polar solvents for AST of plant extracts [91], and is relatively straightforward, rapid, safe and economical to employ. Methanol has demonstrated high extraction efficiency of antimicrobial compounds from Australian plants [95], and allows enhanced diffusion of active compounds through aqueous microbial growth media relative to most other solvents. Given the benefits of investigating the activity of novel extracts of a species (e.g. broader characterisation of antimicrobial activity and secondary metabolome; potential discovery of new therapeutic agents lacking solubility in other solvents), further exploration of polar Australian plant extracts is warranted. Indeed, the present study provides the first report on the antimicrobial activity of polar extracts from multiple tested species.

M. fulgens consistently demonstrated the strongest activity against all tested bacteria $(8 \mathrm{mg} / \mathrm{mL},[4-16 \mathrm{mg} /$ $\mathrm{mL}]$ ), exhibiting significantly higher activity than all non-myrtaceous extracts $(p<0.02$ for all DKW comparisons). In previous studies, $M$. fulgens essential oils have demonstrated insecticidal [96] and acaricidal activity [97], putatively attributed to their abundant 1,8-cineole and limonene content $[96,97]$. The antimicrobial activity of $M$. fulgens had only been previously described for leaf essential oils [98], thus the present study represents the first report on the antimicrobial activity of $M$. fulgens polar extracts. The activity of $M$. fulgens extracts observed herein $(4-16 \mathrm{mg} / \mathrm{mL})$ is significantly lower than was observed for its essential oils (MIC range: $4-8 \mu \mathrm{g}$ / $\mathrm{mL}$ ) against a panel of similar test organisms including E. coli, Salmonella enterica (Gram-negative faecal stormwater organisms) and the skin pathogen Staphylococcus aureus (Gram-positive) [98]. This may be attributed to the relatively poor isolation of many terpenoids and other non-polar $M$. fulgens active compounds by methanolic extraction [94].

C. viminalis extracts demonstrated the most significant activity after $M$. fulgens (median MIC and range for combined organism MIC data: $16 \mathrm{mg} / \mathrm{mL},[2-16 \mathrm{mg} /$ $\mathrm{mL}]$ ). This species has been relatively well-characterised for its antibacterial, antifungal and insecticidal properties, putatively attributed to multiple phenolics, alkaloids, triterpenoids, flavonoids and saponins [99]. Most notably, C. viminalis extracts demonstrated the strongest activity against any individual test organism, specifically E. faecalis $(4 \mathrm{mg} / \mathrm{mL},[2-4 \mathrm{mg} / \mathrm{mL}])$. Salmonella ser. Typhimurium and E. coli demonstrated somewhat lower susceptibilities $(16 \mathrm{mg} / \mathrm{mL}$, [16 mg/mL] and $16 \mathrm{mg} / \mathrm{mL}$, $[8-16 \mathrm{mg} / \mathrm{mL}]$, respectively). Previous studies on foliar methanolic C. viminalis extracts yielded similar findings, with activity tending to be stronger against Gram-positive microorganisms (i.e. skin pathogen Staphylococcus aureus and foodborne disease bacterium Bacillus cereus; average MICs: $0.8 \mathrm{mg} / \mathrm{mL}$ ), than Gram-negative organisms (i.e. E. coli, Shigella sonnei and Pseudomonas aeruginosa: $12.5 \mathrm{mg} / \mathrm{mL}$; Salmonella enteritidis: $6.3 \mathrm{mg} / \mathrm{mL}$ ) [100]. Notably, the activity of C. viminalis against the stormwater faecal microorganisms $E$. coli and Salmonella sp. observed by Delahaye et al. [100] (average MICs 12.5 and $6.3 \mathrm{mg} / \mathrm{mL}$ respectively) were very similar to the present findings (E. coli and Salmonella ser. Typhimurium MIC range: $8-16 \mathrm{mg} / \mathrm{mL}$ ).

Also of interest was the high activity demonstrated by $L$. lanigerum $(8 \mathrm{mg} / \mathrm{mL},[4-16 \mathrm{mg} / \mathrm{mL}])$. To our knowledge, no previous studies have characterised the antimicrobial activity of this species, notwithstanding biochemical profiles demonstrating significant levels of antimicrobial-associated secondary metabolites [101]. These include the monoterpenoids $\alpha$-pinene $(0.5-20 \%$ oil content), $\beta$-pinene (1-21\%) [102], 1,8-cineole (3-7\%) [103], linalool (0.4-3\%) and $\alpha$-terpineol (2-3\%) [104], in addition to the sesquiterpenes $\beta$-caryophyllene (13 $\pm 57 \%)$ [105] and humulene $(2 \pm 22 \%)$ [106]. Given the observed similarity in activity of $L$. lanigerum in this study to the much better characterised $C$. viminalis, the antimicrobial activity of this species warrants further investigation.

The above three top-performing species exhibited significantly higher activities than all non-myrtaceous extracts $(P<0.02$ for all non-myrtaceous vs. $M$. fulgens, $C$. viminalis and L. lanigerum comparisons; DKW test). Of key interest is that the current biofilter gold standard for pollutant removal, Carex appressa, demonstrated one of the lowest observed activities of tested plants against all reference microorganisms $(64 \mathrm{mg} / \mathrm{mL} ;[32-64 \mathrm{mg} / \mathrm{mL}])$, up to eight-fold lower than the best performer $M$. fulgens. To our knowledge, this is the first report on the antimicrobial activity of C. appressa. There is little available information on its chemical constituents, although two compounds with potential antimicrobial activity, namely the aurone sulfuretin [107] and the flavonoid tricin [108], have been identified in small amounts in its tissues [109]. These or other unidentified compounds likely contributed to the observed sparing activity of $C$. appressa extracts.

G. pulchella and P. myoporoides exhibited the weakest activity of test candidates, notably against E. faecalis (> $64 \mathrm{mg} / \mathrm{mL} ;[64$ - > $64 \mathrm{mg} / \mathrm{mL}]$ ), demonstrating only some modest activity against other test organisms ( $P$. myoporoides and G. pulchella against E. coli: $32 \mathrm{mg} / \mathrm{mL}$, [32-64 $\mathrm{mg} / \mathrm{mL}] ;$ P. myoporoides against Salmonella ser. Typhimurium: $32 \mathrm{mg} / \mathrm{mL},[32-64 \mathrm{mg} / \mathrm{mL}])$. G. pulchella has 
not been previously characterised for its antimicrobial activity or metabolites. The sparing activity observed for $P$. myoporoides extracts may be attributed to its production of small amounts of metabolites with established antimicrobial (e.g. the terpenoid $\alpha$-pinene [110]) or putatively antimicrobial (e.g. sesquiterpenyl coumarins and geranyl benzaldehyde derivatives) activity $[110,111]$. The low overall activity of $P$. myoporoides is consistent with a previous AST study, where a $4 \mathrm{mg} / \mathrm{mL}$ methanolic leaf extract was observed to lack significant inhibition of similar organisms (E. coli and Salmonella ser. Typhimurium) among others [94].

Unexpectedly, M. lanceolata demonstrated significantly lower activity compared to other tested myrtaceous plants $(32 \mathrm{mg} / \mathrm{mL}, \quad[16-64 \mathrm{mg} / \mathrm{mL}] ; p<0.0001$, uncorrected MW test for M. lanceolata vs. combined myrtaceous plant data). Previous investigations on the activity of this species remain limited, although its essential oils have reported insecticidal activity [96] and moreover contain various antimicrobial-associated compounds (1,8-cineole, globulol, sesquiterpenes and $\alpha$-pinene) [112]. Aside from organism-specific differences in susceptibility (insecticidal vs. bactericidal), extraction method may have accounted for the low inhibitory activity observed in the present study. Polar extracts may underrepresent the activity of plants containing significant proportions of non-polar antimicrobial compounds. Indeed, a similar lack of antimicrobial activity was observed for polar (aqueous) M. lanceolata extracts in a previous study [113]. Furthermore, single extracts may not reflect complex synergistic/antagonistic effects against microorganisms by plants in natura. This is a reminder that the present study solely provides a rapid screening method for estimating plant antimicrobial activity; multiple AST methods are recommended to provide more holistic antimicrobial characterisation.

\section{Variability in antimicrobial activities between test organisms}

Myrtaceous plant extracts consistently exhibited comparatively strong activity against the Gram-positive bacterium E. faecalis $(8 \mathrm{mg} / \mathrm{mL}, \quad[2-32 \mathrm{mg} / \mathrm{mL}])$ than against Gram-negative organisms Salmonella ser. Typhimurium and E. coli $(p<0.0001$ for individual DKW and combined MW MIC data comparisons). The latter two organisms, both members of the Enterobacteriaceae, demonstrated high similarity in their MIC distributions (median and range of both: $16 \mathrm{mg} / \mathrm{mL},[8-64 \mathrm{mg} / \mathrm{mL}$ ]; $p>0.9999$; DKW test between E. coli and Salmonella ser. Typhimurium total data), likely attributed to their high genetic relatedness [114]. E. faecalis did not demonstrate significantly greater susceptibility to non-myrtaceous W. fruticosa, P. myoporoides, G. pulchella and $C$. appressa extracts, suggesting a comparative lack of antimicrobial compounds produced by these plants with Enterococcus- or Gram-positive-specific activity.

The relative susceptibility of Gram-positive to Gram-negative bacteria against plant extracts has been observed previously. The comparative resistance of Gram-negative organisms has been explained by their possession of an outer membrane, which acts as an effective barrier to amphipathic antimicrobial compounds [115-117]. Overexpressed or multiple efflux pumps in Gram-negative bacteria have moreover been associated with enhancing the transport of antimicrobial substances out of the cell $[118,119]$. More specifically, Enterobacteriaceae are often reported to demonstrate greater inhibition to myrtaceous plant extracts than enterococci [120-123]. This has been putatively ascribed to abundant polyphenol production in myrtaceous plants, which can facilitate cytoplasmatic membrane damage and inhibit the synthesis of cell walls, cell membranes and nucleic acids [120]. Nevertheless, the specific identities of Gram-positive active compounds isolated from polar Australian myrtaceous plant extracts remain vastly uncharacterised [124].

\section{Intra-species variability in antimicrobial activity}

Aside from inter-species variation, differences in extract activity were occasionally observed between unique biological individuals derived from the same species. Equivalent or very similar activities were observed for individual replicates of the same species (MICs \pm 1 dilution of each other for all test organisms), with the exception of M. ericifolia, M. hypericifolia (both $4-16 \mathrm{mg} / \mathrm{mL}$ for E. faecalis) and M. linariifolia $(8-32 \mathrm{mg} / \mathrm{mL}$ for Salmonella ser. Typhimurium), demonstrating up to four-fold differences in activity between replicates (MICs \pm 2 dilutions of each other; all MICs listed in Additional file 1: Table S3). Observed disparities in activity between biological replicates remained consistent despite confirmatory testing on new, independently prepared extracts from the same plants.

Individuals of the same species often demonstrate equivalent or very similar activities even when cultivated in distinct environments, as was observed for most candidates in the present study [125-127]. However, inconsistencies in activity can arise due to differing levels of exposure to various biotic and abiotic stresses. Indeed, applying various stressing conditions has established efficacy for enhancing secondary metabolite production, including antimicrobials, in plants [54]. Upon further investigation, the $M$. hypericifolia individual demonstrating the lowest activity against E. faecalis (MIC $=16 \mathrm{mg}$ / $\mathrm{mL}$ ) was situated in a more shaded, higher altitude site with higher rainfall relative to other sampling locations (Karwarra Garden, Mt. Dandenong, 420-440 m AMSL, 
mean annual rainfall: $1262.3 \mathrm{~mm}$ ). Conversely, the $M$. hypericifolia individual with the highest $E$. faecalis inhibitory activity $(\mathrm{MIC}=4 \mathrm{mg} / \mathrm{mL})$ was situated in a much drier, lower altitude location (Maranoa Gardens, Balwyn, $100 \mathrm{~m}$ AMSL, mean annual rainfall: 686.5 $\mathrm{mm})$. A corresponding trend was observed among the most and least active $M$. linariifolia replicates against Salmonella ser. Typhimurium (MIC $=8 \mathrm{mg} / \mathrm{mL}$ vs. 32 $\mathrm{mg} / \mathrm{mL}$ ), with the former being planted in a drier, more exposed location than the latter. Similar observations have been recorded previously, where individuals grown in drier $[56,57]$ and hotter locations have demonstrated higher antimicrobial production than those from lower altitude sites with cooler, wetter climates [58]. Changes in antimicrobial production under water stress may be particularly relevant in the context of biofilters, where plants commonly withstand extended drying periods. Moisture, temperature or other unmonitored parameters such as UV exposure, soil nutrient levels, intrinsic plant factors (e.g. age, genetic factors/chemotype) and predation/infection by pathogens may have accounted for observed activity disparities between replicates. The differential production of antimicrobial compounds between unique individuals under varying operational conditions may have significant implications for vegetation-mediated pathogen removal within biofilters.

\section{Vegetation selection for antimicrobial biofilters}

The results of this study suggest that many myrtaceous species, particularly $M$. fulgens, $C$. viminalis and $L$. lanigerum, may enhance biofilter-mediated pathogen removal relative to $C$. appressa and other non-myrtaceous plants. Indeed, certain Melaleuca and Leptospermum species have previously demonstrated high faecal microorganism removal in stormwater biofilters [22] and $E$. coli-contaminated soil [65]. While these top performing species have been recommended by various biofilter vegetation selection guidelines based on practicality and survivability [69], they have not been specifically identified for enhancing pollutant removal. We recommend further investigation of the in natura antimicrobial activity of these species against multiple stormwater pathogens within biofilters. In contrast, other species in this paper demonstrated poor activity relative to other candidates, and may be cautiously advised against for antimicrobial vegetation selection.

In line with previous research, the results of this study reveal varying susceptibilities of different microorganisms to plant extracts. This highlights the challenge in selecting universally effective vegetation for the removal of all stormwater pathogens, particularly Gram-negative bacteria. Many important stormwater faecal pathogens are Gram-negative, including Salmonella sp., Campylobacter sp. and pathogenic E. coli O157:H7. Further research is required to determine the efficacy of plant-mediated antimicrobial treatment of viral, protozoan and other bacterial stormwater pathogens in vitro and within biofilters. Indeed, the inherently differing susceptibilities of stormwater microorganisms to different plant antimicrobials raises the case for incorporating mixed plant communities into biofilters for multilateral treatment.

Significant four-fold differences between species individuals were occasionally observed. Intrinsic and environmental factors influencing plant secondary metabolism inherently differ within (temporally) and between biofilters depending on specific system design (e.g. incorporation of a SZ, filter media type) and operational conditions (e.g. surrounding land use, seasonal, climatic and hydrologic factors). The differential influence of these variables on the quality and quantity of plant antimicrobials deposited into biofilters may affect the extent of vegetation-mediated pathogen removal. Addressing the current knowledge gaps surrounding this phenomenon will inform vegetation guidelines for optimal performance. More broadly, while not being common practice in plant AST studies, our findings highlight the importance of testing multiple biological replicates from diverse environments to adequately reflect natural variability in antimicrobial activity of a given species. Incorporating routine multi-replicate testing is thus strongly recommended for strengthening method design in prospective studies within plant pharmacology.

\section{Conclusions}

The methanolic leaf extracts of 17 plant species, selected for their suitability in south-eastern Australian stormwater biofilters, were investigated for their antimicrobial activities against common stormwater bacteria E. coli, Salmonella ser. Typhimurium and E, faecalis. The employed selection and testing method was validated as a safe, simple, rapid and inexpensive preliminary screening approach to select biofilter-suitable plant species with antimicrobial activity (based on a Melbourne case study).

Our results suggest that myrtaceous plants, particularly M. fulgens, $C$. viminalis and L. lanigerum, may enhance pathogen inactivation within biofilters relative to poorer performing non-myrtaceous plants. Notably, these species are predicted to demonstrate enhanced pathogen treatment relative to the current biofilter vegetation gold standard, C. appressa. Further investigation of these high-performing species for their pathogen removal in biofilter contexts is recommended. Notably, the activity of plant species often varied against different microorganisms. This suggests that integrating multiple 
high-performing plants into biofilters may achieve optimal pathogen killing efficacy.

Occasional significant differences in activity were observed between different species replicates, suggesting that biofilter operational conditions (e.g. extended drying periods, high temperatures, high UV exposure) may influence plant antimicrobial production and thus overall treatment. Testing multiple genetically and environmentally diverse individuals appears to be essential for accurate antimicrobial characterisation of a species. This practice is uncommon in plant AST studies and thus forms an important recommendation of this research.

On a broader note, further research into the activity of these plant species against other clinically significant microorganisms, particularly under-researched candidates like L. lanigerum, may elucidate candidates for future development of novel antimicrobial agents.

\section{Additional file}

Additional file 1: Complete experimental data for selected test plant species. (DOCX $106 \mathrm{~kb})$

\section{Abbreviations}

AST: antimicrobial susceptibility testing; CFU: colony forming unit(s); DKW: Dunn's corrected Kruskal-Wallis; DMSO: dimethyl sulfoxide; E. coli: Escherichia coli; E. faecalis: Enterococcus faecalis; FIO: Faecal indicator organism; INT: 2-p-iodophenyl-3-p-nitrophenyl-5-phenyl tetrazolium chloride; MHB: Mueller-Hinton broth; MW: Mann-Whitney; OD: optical density; PBMW: post hoc Bonferroni-corrected Mann-Whitney; rpm: rotations per minute; Salmonella ser. Typhimurium: Salmonella enterica subsp. enterica ser. Typhimurium; SZ: submerged zone; WSUD: Water sensitive urban design

\section{Acknowledgments}

The authors wish to acknowledge the support of Richard Williamson and Christelle Schang (Monash University, Clayton, VIC), Evan Cluclas (Karunga Nursery, Mount Evelyn VIC), Mark Correa (Grounds Curator/Senior Contracts Specialist at Monash University, Clayton, VIC), Damian Carr (City of Bayside Council, Sandringham, VIC), Andrea Dennis and Paul Birch (curators of Maranoa Gardens, Balwyn, VIC), Peter Tucker (Biodiversity Sites and Revegetation crew member, Boroondara Council Biodiversity Working Group Balywyn, VIC), Robert Galbraith (arborist, Camberwell, VIC), John Bentleigh (2016 Treasurer at Friends of Melton Botanic Garden, Melton, VIC), Jill Kellow (Friends of Burnely Botanic Gardens, Burnley, VIC), Michael Cincotta (horticulturalist at Latrobe Wildlife Sanctuary, Bundoora, VIC), Shelley Wood and Lindy Harris (horticulturalists with Friends of Karwarra Garden, Kalorama, VIC), Peter Syme, Warren Worboys and Steven Liu (horticulturalists, Royal Botanic Gardens Victoria, South Yarra and Cranbourne VIC).

\section{Funding}

This study was funded by the Australian Research Council, the Discovery Early Career Researcher Award [DE140100524].

\section{Availability of data and materials}

All data collected or analysed during this study are included in this published article and its Additional file 1: Table S1.

\section{Authors' contributions}

PG: Conceptualization, Data curation, Formal analysis, Investigation, Methodology, Project administration, Visualization, Writing - original draft, Writing - review \& editing. RH: Conceptualization, Methodology, Project administration, Supervision, Writing - review \& editing. DM:

Conceptualization, Funding acquisition, Methodology, Project administration,
Supervision, Writing - review \& editing. All authors read and approved the final manuscript.

\section{Ethics approval and consent to participate}

Not applicable.

\section{Consent for publication}

This manuscript is approved by all authors for publication.

\section{Competing interests}

The authors' declare that they have no competing interests.

\section{Publisher's Note}

Springer Nature remains neutral with regard to jurisdictional claims in published maps and institutional affiliations.

Received: 10 January 2019 Accepted: 6 May 2019

Published online: 06 June 2019

\section{References}

1. Riley MR, Gerba CP, Elimelech M. Biological approaches for addressing the grand challenge of providing access to clean drinking water. J Biol Eng. 2011;5(1):2.

2. Tippler C, Wright IA, Hanlon A. Is catchment imperviousness a keystone factor degrading urban waterways? A case study from a partly urbanised catchment (Georges River, South-Eastern Australia). Water Air Soil Pollut. 2012:223(8):5331-44

3. McCarthy D, Hathaway J, Hunt W, Deletic A. Intra-event variability of Escherichia coli and total suspended solids in urban stormwater runoff. Water Res. 2012;46(20):6661-70

4. Makepeace DK, Smith DW, Stanley SJ. Urban stormwater quality: summary of contaminant data. Crit Rev Env Sci Tec. 1995;25(2):93-139.

5. NRMMC E. NHMRC, Australian guidelines for water recycling (phase 2): Stormwater harvesting and reuse. Natural resource management ministerial council, environment protection and Heritage Council, National Health and Medical Research Council, Canberra, Australia. 2009.

6. Olivieri A, Boehm A, Sommers CA, Soller JA, Eisenberg JN, Danielson R. Development of a protocol for risk assessment of microorganisms in separate Stormwater systems: Water Environment Research Foundation; 2007.

7. Paton JC, Paton AW. Pathogenesis and diagnosis of Shiga toxin-producing Escherichia coli infections. Clin Microbiol Rev. 1998:11(3):450-79.

8. NHMRC. Australian Drinking water guidelines. National Health and Medical Research Council Australia, 2004

9. Lopez-Ponnada EV, Lynn TJ, Peterson M, Ergas SJ, Mihelcic JR. Application of denitrifying wood chip bioreactors for management of residential nonpoint sources of nitrogen. J Biol Eng. 2017;11(1):16.

10. Payne EGI, Hatt BE, Deletic A, Dobbie MF, McCarthy DT, Chandrasena GI. Adoption guidelines for Stormwater biofiltration systems. Melbourne, Australia: Cooperative Research Centre for Water Sensitive Cities; 2015.

11. FAWB. Adoption guidelines for Stormwater biofiltration systems. Melbourne, Australia: Facility for Advancing Water Biofiltration, Monash University, 2009.

12. Hathaway J, Hunt W, Graves A, Wright J. Field evaluation of bioretention indicator bacteria sequestration in Wilmington, North Carolina. J Environ Eng. 2011;137(12):1103-13.

13. Zinger $Y$, Deletic A, Fletcher T, Breen P, Wong T, Editors. A dual-mode biofilter system: case study in Kfar Sava, Israel. Proceedings of the 12th international conference on urban drainage; 2011; Porto Alegre, Brazil.

14. Zhang L, Seagren EA, Davis AP, Karns JS. Long-term sustainability of Escherichia coli removal in conventional bioretention media. J Env Eng. 2011;137(8):669-77.

15. Schifman LA, Kasaraneni VK, Sullivan RK, Oyanedel-Craver V, Boving TB. New Antimicrobially amended Media for Improved Nonpoint Source Bacterial Pollution Treatment. Env Sci Tec. 2015:49(24):14383-91.

16. Li YL, Deletic A, Alcazar L, Bratieres K, Fletcher TD, McCarthy DT. Removal of Clostridium perfringens, Escherichia coli and F-RNA coliphages by stormwater biofilters. Ecol Eng. 2012;49:137-45.

17. Rusciano G, Obropta C. Bioretention column study: fecal coliform and total suspended solids reductions. T ASABE. 2007;50(4):1261-9. 
18. Chandrasena G, Deletic A, Ellerton J, McCarthy D. Evaluating Escherichia coli removal performance in stormwater biofilters: a laboratory-scale study. Wat Sci Tec. 2012;66(5):1132-8.

19. Zhang L, Seagren EA, Davis AP, Karns JS. Effects of temperature on bacterial transport and destruction in bioretention media: field and laboratory evaluations. Wat Env Res. 2012;84(6):485-96.

20. Chandrasena Gl, Filip S, Zhang K, Osborne CA, Deletic A, McCarthy DT, editors. Pathogen and indicator microorganism removal in field scale stormwater biofilters. WSUD 2012: Water sensitive urban design; Building the water sensitive community; 7th international conference on water sensitive urban design; 2012; Barton, A.C.T.: Engineers Australia.

21. Li Y, McCarthy DT, Deletic A. Escherichia coli removal in copper-zeoliteintegrated stormwater biofilters: effect of vegetation, operational time, intermittent drying weather. Ecol Eng. 2016;90:234-43.

22. Chandrasena G, Pham T, Payne E, Deletic A, McCarthy DE. Coli removal in laboratory scale stormwater biofilters: influence of vegetation and submerged zone. J Hydrol. 2014;519:814-22.

23. Pecson BM, Decrey L, Kohn T. Photoinactivation of virus on iron-oxide coated sand: enhancing inactivation in sunlit waters. Water Res. 2012;46(6): 1763-70.

24. Mohanty SK, Torkelson AA, Dodd H, Nelson KL, Boehm AB. Engineering solutions to improve the removal of fecal indicator bacteria by bioinfiltration systems during intermittent flow of stormwater. Env Sci Tec. 2013;47(19):10791-8

25. Zhang L, Seagren EA, Davis AP, Karns JS. The capture and destruction of Escherichia coli from simulated urban runoff using conventional bioretention media and iron oxide-coated sand. Water environment research : a research publication of the Water Environment Federation. 2010;82(8):701-14.

26. Li YL, Deletic A, McCarthy DT. Removal of E. coli from urban stormwater using antimicrobial-modified filter media. J Haz Mat. 2014;271:73-81.

27. Li YL, McCarthy DT, Deletic A. Stable copper-zeolite filter media for bacteria removal in stormwater. J Haz Mat. 2014;273:222-30.

28. Guest R, Schang C, Deletic A, McCarthy D. Zinc-sulphate-heptahydrate coated activated carbon for microbe removal from stormwater. Wat Sci Tec. 2012:66(7):1582-9.

29. Payne $\mathrm{EGl}$. The influence of plant species and water dynamics on nitrogen removal within Stormwater biofilters [thesis for the degree of doctor of philosophy, civil engineering]. Melbourne, Australia: Monash University; 2013.

30. Breen PF. A mass balance method for assessing the potential of artificial wetlands for wastewater treatment. Water Res. 1990;24(6):689-97.

31. Fritioff $\AA$, Greger M. Aquatic and terrestrial plant species with potential to remove heavy metals from stormwater. Int J Phytoremediation. 2003;5(3): 211-24.

32. Stevik TK, Aa K, Ausland G, Hanssen JF. Retention and removal of pathogenic bacteria in wastewater percolating through porous media: a review. Water Res. 2004:38(6):1355-67.

33. Stott $R$, Tanner $C$. Influence of biofilm on removal of surrogate faecal microbes in a constructed wetland and maturation pond. Wat Sci Tec. 2005; 51(9):315-22.

34. Philippot L, Raaijmakers JM, Lemanceau P, Van Der Putten WH. Going back to the roots: the microbial ecology of the rhizosphere. Nat Rev Microbiol. 2013;11(11):789.

35. Gregory PJ, Hinsinger P. New approaches to studying chemical and physical changes in the rhizosphere: an overview. Plant Soil. 1999;211(1):1-9.

36. Loss S, Robson A, Ritchie G. H+/OH-excretion and nutrient uptake in upper and lower parts of lupin (Lupinus angustifolius L.) root systems. Ann Bot. 1993;72(4):315-20

37. Soto F, Garcia M, De Luis E, Becares E. Role of Scirpus lacustris in bacterial and nutrient removal from wastewater. Wat Sci Tec. 1999:40(3):241-7.

38. Stottmeister U, Wießner A, Kuschk P, Kappelmeyer U, Kästner M, Bederski O, et al. Effects of plants and microorganisms in constructed wetlands for wastewater treatment. Biotechnol Adv. 2003;22(1-2):93-117.

39. García J, Rousseau DPL, Morató J, Lesage E, Matamoros V, Bayona JM. Contaminant removal processes in subsurface-flow constructed wetlands: a review. Crit Rev Env Sci Tec. 2010;40(7):561-661.

40. Brix H. Do macrophytes play a role in constructed treatment wetlands? Wat Sci Tec. 1997;35(5):11-7.

41. Vymazal J. Removal of enteric bacteria in constructed treatment wetlands with emergent macrophytes: a review. J Environ Sci Health A Tox Hazard Subst Environ Eng. 2005;40(6-7):1355-67.
42. Chandrasena Gl, Shirdashtzadeh M, Li YL, Deletic A, Hathaway JM, McCarthy DT. Retention and survival of E. coli in stormwater biofilters: role of vegetation, rhizosphere microorganisms and antimicrobial filter media. Ecol Eng 2017;102(Supplement C):166-177.

43. Shirdashtzadeh M, Chandrasena G, Henry R, McCarthy D. Plants that can kill; improving E. coli removal in stormwater treatment systems using Australian plants with antibacterial activity. Ecol Eng. 2017;107:120-5.

44. Cock IE. Antibacterial activity of selected Australian native plant extracts. Internet J Microbiol. 2008:4(2):1-8.

45. Kurekci C, Bishop-Hurley SL, Vercoe PE, Durmic Z, Al Jassim RA, McSweeney CS. Screening of Australian plants for antimicrobial activity against campylobacter jejuni. Phytother Res. 2012;26(2):186-90.

46. Carson C, Hammer K, Riley T. Melaleuca alternifolia (tea tree) oil: a review of antimicrobial and other medicinal properties. Clin Microbiol Rev. 2006;19(1): 50-62.

47. Prosser JA, Anderson CWN, Horswell J, Speir TW. Can manuka (Leptospermum scoparium) antimicrobial properties be utilised in the remediation of pathogen contaminated land? Soil Biol Biochem. 2014;75: 167-74.

48. Cock IE. Antimicrobial activity of Acacia aulacocarpa and Acacia complanta methanolic extracts. Phcog Commn. 2012;2(1):66-71.

49. Palombo EA, Semple SJ. Antibacterial activity of Australian plant extracts against methicillin-resistant Staphylococcus aureus (MRSA) and vancomycinresistant enterococci (VRE). J Basic Microbiol. 2002;42(6):444-8.

50. Gilles M, Zhao J, An M, Agboola S. Chemical composition and antimicrobial properties of essential oils of three Australian Eucalyptus species. Food Chem. 2010;119(2):731-7.

51. Chandrasena G, Deletic A, McCarthy D. Survival of Escherichia coli in stormwater biofilters. Environ Sci Pollut Res. 2014;21(8):5391-401.

52. Zhang $Y$, Hunt HK, Hu Z. Application of bacteriophages to selectively remove Pseudomonas aeruginosa in water and wastewater filtration systems. Water Res. 2013:47(13):4507-18.

53. Kainulainen $\mathrm{P}$, Holopainen JK. Concentrations of secondary compounds in scots pine needles at different stages of decomposition. Soil Biol Biochem. 2002;34(1):37-42.

54. Gomes da Silva F, Pereira Horta L, de Oliveira Faria R, Renato Stehmann J, Valentina Modolo L. Stressing conditions as tools to boost the biosynthesis of valuable plant natural products. Recent Pat Biotechnol. 2014;8(1):89-101.

55. Jung J-K, Lee S-U, Kozukue N, Levin CE, Friedman M. Distribution of phenolic compounds and antioxidative activities in parts of sweet potato (Ipomoea batata L.) plants and in home processed roots. J Food Compost Anal. 2011;24(1):29-37.

56. Sung Y, Chang Y-Y, Ni-Lun T. Capsaicin biosynthesis in water-stressed hot pepper fruits. Bot Bull Acad Sinica. 2005;46.

57. Phimchan P, Techawongstien S, Chanthai S, Bosland PW. Impact of drought stress on the accumulation of capsaicinoids in Capsicum cultivars with different initial capsaicinoid levels. HortScience. 2012;47(9):1204-9.

58. Ortega-Nieblas MM, Robles-Burgueño MR, Acedo-Félix E, González-León A, Morales-Trejo A, Vázquez-Moreno L. Chemical composition and antimicrobial activity of oregano (Lippia palmeri S. WATS) essential oil. Rev Fitotec Mex. 2011;34(1).

59. Lee SC, Hwang BK. Functional roles of the pepper antimicrobial protein gene, CaAMP1, in abscisic acid signaling, and salt and drought tolerance in Arabidopsis. Planta. 2009;229(2):383-91.

60. Attiwill P, Guthrie H, Leuning R. Nutrient cycling in a Eucalyptus obliqua (L'Herit.) forest. I. Litter production and nutrient return. Aus J Bot. 1978;26(1): 79-91.

61. Ens E-J, French K, Bremner JB. Evidence for allelopathy as a mechanism of community composition change by an invasive exotic shrub, Chrysanthemoides monilifera spp. rotundata. Plant Soil. 2009;316(1-2): 125-37.

62. Mitchell G, Bartlett DW, Fraser TE, Hawkes TR, Holt DC, Townson JK, et al. Mesotrione: a new selective herbicide for use in maize. Pest Manag Sci. 2001:57(2):120-8.

63. Cornes D, Editor Callisto: a very successful maize herbicide inspired by allelochemistry. Proceedings of the 4th world congress on allelopathy, "establishing the Scientific Base", Wagga Wagga, New South Wales, Australia, 21-26 august 2005; 2005: Centre for Rural Social Research, Charles Sturt University.

64. Jeong E-Y, Lee M-J, Lee H-S. Antimicrobial activities of leptospermone isolated from Leptospermum scoparium seeds and structure-activity 
relationships of its derivatives against foodborne bacteria. Food Sci Biotechnol. 2018;27(5):1541-7.

65. Prosser JA, Woods RR, Horswell J, Robinson BH. The potential in-situ antimicrobial ability of Myrtaceae plant species on pathogens in soil. Soil Biol Biochem. 2016;96:1-3.

66. Lamb DT, Ming $H$, Megharaj M, Naidu R. Relative tolerance of a range of Australian native plant species and lettuce to copper, zinc, cadmium, and lead. Arch Environ Contam Toxicol. 2010;59(3):424-32.

67. Vance CP, Uhde-Stone C, Allan DL. Phosphorus acquisition and use: critical adaptations by plants for securing a nonrenewable resource. New Phytol. 2003;157(3):423-47.

68. Read J, Fletcher TD, Wevill T, Deletic A. Plant traits that enhance pollutant removal from stormwater in biofiltration systems. Int J Phytoremediation. 2010;12(1):34-53.

69. Payne EGI, Pham T, Cook PLM, Deletic A, Hatt BE, Fletcher TD. Inside story of gas processes within Stormwater biofilters: does greenhouse gas production tarnish the benefits of nitrogen removal? Env Sci Tec. 2017:51(7): 3703-13.

70. Read J, Wevill T, Fletcher T, Deletic A. Variation among plant species in pollutant removal from stormwater in biofiltration systems. Water Res. 2008; 42(4):893-902.

71. Oversby B, Payne E, Fletcher T, Byleveld G, Hatt B. Vegetation guidelines for stormwater biofilters in the south-west of Western Australia. Melbourne, Victoria: Water for Liveability Centre, Monash University, 2014.

72. Danjon F, Stokes A, Bakker MR. Root systems of woody plants. In: Eshel A, Beeckman T, editors. Plant Roots: The Hidden Half. 4 ed. Boca Raton, Florida: CRC Press; 2013. p. 29.1-.1.

73. van Hengstum T, Hooftman DAP, Oostermeijer JGB, van Tienderen PH. Impact of plant invasions on local arthropod communities: a meta-analysis. J Ecol. 2014;102(1):4-11.

74. H.C.C. Hume City Council recommended species list. Melbourne, Australia: 2013.

75. Dixon RA. Natural products and plant disease resistance. Nature. 2001; 411(6839):843-7.

76. Vicflora. Flora of Victoria Key to the Tracheophyta [cited 2016 29/09/16-17/ 11/16]. Available from: https://vicflora.rbg.vic.gov.au/flora/key/1903.

77. PlantNET. The NSW plant information network system Royal Botanic Gardens and domain trust, Sydney [cited 2016 29/09/16 - 17/11/16] Available from: http://plantnet.rbgsyd.nsw.gov.au.

78. Wright MH, Greene AC, Cock IE. Inhibition of bacillus anthracis growth by Australian native plants used traditionally as antibacterial medicines. Phcog J. 2015;7:6.

79. Hübsch Z, Van Zyl R, Cock I, Van Vuuren S. Interactive antimicrobial and toxicity profiles of conventional antimicrobials with southern African medicinal plants. S Afr J Bot. 2014;93:185-97.

80. Achtman M, Hale J, Murphy RA, Boyd EF, Porwollik S. Population structures in the SARA and SARB reference collections of Salmonella enterica according to MLST, MLEE and microarray hybridization. Infect Genet Evol. 2013;16:314-25.

81. Joshi S, Bisht GS, Rawat DS, Kumar A, Kumar R, Maiti S, et al. Interaction studies of novel cell selective antimicrobial peptides with model membranes and E. coli ATCC 11775. Biochim Biophys Acta Biomembr. 2010; 1798(10):1864-75

82. Okeke MI, Iroegbu CU, Eze EN, Okoli AS, Esimone CO. Evaluation of extracts of the root of Landolphia owerrience for antibacterial activity. J Ethnopharmacol. 2001;78(2-3):119-27.

83. CLSI. M07-A10. Methods for dilution antimicrobial susceptibility tests for bacteria that grow aerobically; approved standard- tenth edition. Clinical and laboratory standards institute; 2015.

84. Sutton S. Measurement of cell concentration in suspension by optical density. Microbiol. 2006:585:210-8336.

85. Klančnik A, Piskernik S, Jeršek B, Možina SS. Evaluation of diffusion and dilution methods to determine the antibacterial activity of plant extracts. $J$ Microbiol Methods. 2010;81(2):121-6.

86. Eloff JN. A sensitive and quick microplate method to determine the minimal inhibitory concentration of plant extracts for bacteria. Planta Med 1998;64(08):711-3.

87. Raad I, Hanna H, Jiang Y, Dvorak T, Reitzel R, Chaiban G, et al. Comparative activities of daptomycin, linezolid, and tigecycline against catheter-related methicillin-resistant Staphylococcus bacteremic isolates embedded in biofilm. Antimicrob Agents Chemother. 2007;51(5):1656-60.
88. Markowska K, Grudniak AM, Krawczyk K, Wrobel I, Wolska Kl. Modulation of antibiotic resistance and induction of a stress response in Pseudomonas aeruginosa by silver nanoparticles. J Med Microbiol. 2014;63(6):849-54.

89. Mpala LN, Chikowe GR, Cock IE. Growth inhibitory properties of extracts prepared from selected Leptospermum and Melaleuca species against a panel of pathogenic bacteria. Phcog Commn. 2016;6(4).

90. Reller LB, Weinstein M, Jorgensen JH, Ferraro MJ. Antimicrobial susceptibility testing: a review of general principles and contemporary practices. Clin Infect Dis. 2009:49(11):1749-55.

91. Ncube N, Afolayan A, Okoh A. Assessment techniques of antimicrobial properties of natural compounds of plant origin: current methods and future trends. Afr J Biotech. 2008;7(12).

92. Van Vuuren S, Docrat Y, Kamatou G, Viljoen A. Essential oil composition and antimicrobial interactions of understudied tea tree species. S Afr J Bot. 2014;92:7-14.

93. Abdelhady Ml, Aly HAH. Antioxidant antimicrobial activities of callistemon comboynensis essential oil. Free Rad Antiox. 2012;2(1):37-41.

94. Wigmore SM, Naiker M, Bean DC. Antimicrobial activity of extracts from native plants of temperate Australia. Phcog Commn. 2016;6(2).

95. Sautron C, Cock IE. Antimicrobial activity and toxicity of Syzygium australe and Syzygium leuhmannii fruit extracts. Phcog Commn. 2014;4(1):53.

96. Lee $\mathrm{B}-\mathrm{H}$, Annis PC, Choi W-S. Fumigant toxicity of essential oils from the Myrtaceae family and 1,8-cineole against 3 major stored-grain insects. J Stored Prod Res. 2004;40(5):553-64.

97. Roh HS, Lee BH, Park CG. Acaricidal and repellent effects of myrtacean essential oils and their major constituents against Tetranychus urticae (Tetranychidae). J Asia Pac Entomol. 2013;16(3):245-9.

98. Siddique S, Parveen Z, Mazhar S. Chemical composition, antibacterial and antioxidant activities of essential oils from leaves of three Melaleuca species of Pakistani flora. Arab J Chem. 2017.

99. Salem MZM, El-Hefny M, Nasser RA, Ali HM, El-Shanhorey NA, Elansary HO Medicinal and biological values of Callistemon viminalis extracts: history, current situation and prospects. Asian Pac J Trop Med. 2017;10(3):229-37.

100. Delahaye C, Rainford L, Nicholson A, Mitchell S, Lindo J, Ahmad M. Antibacterial and antifungal analysis of crude extracts from the leaves of Callistemon viminalis. J Med Biol Sci. 2009:3(1):1-7.

101. Brophy JJ, Goldsack RJ, Bean AR, Forster PI, Lepschi BJ. Leaf essential oils of the genus Leptospermum (Myrtaceae) in eastern Australia. Part 3. Leptospermum arachnoides and allies. Flavour Fragr J. 1999;14(2):85-91.

102. Leite AM, Lima EO, ELd S, Diniz MFFM, Trajano VN, IAd M. Inhibitory effect of beta-pinene, alpha-pinene and eugenol on the growth of potential infectious endocarditis causing gram-positive bacteria. Revista Brasileira de Ciências Farmacêuticas. 2007;43(1):121-6.

103. Vuuren Sv VA. Antimicrobial activity of limonene enantiomers and 1, 8cineole alone and in combination. Flavour Fragr J. 2007;22(6):540-4.

104. Park S-N, Lim YK, Freire MO, Cho E, Jin D, Kook J-K. Antimicrobial effect of linalool and a-terpineol against periodontopathic and cariogenic bacteria. Anaerobe. 2012:18(3):369-72

105. Kim Y, Park S, Lee E, Cerbo R, Lee S, Ryu C, et al. Antibacterial compounds from rose Bengal-sensitized photooxidation of $\beta$-caryophyllene. J Food Sci. 2008;73(7):C540-C5

106. Sözer U, Dömnez AA, Meriçli AH. Constituents from the leaves of Crataegus davisii Browicz. Sci Pharm. 2006;74(4):203-8.

107. Kang SY, Kang JY, Oh MJ. Antiviral activities of flavonoids isolated from the bark of Rhus verniciflua stokes against fish pathogenic viruses in vitro. J Microbiol. 2012;50(2):293-300.

108. Ju Y, Sacalis JN, Still CC. Bioactive flavonoids from endophyte-infected blue grass (Poa ampla). J Ag Food Chem. 1998;46(9):3785-8.

109. Harborne BJ, Williams AC, Wilson LK. Flavonoids in leaves and inflorescences of australian cyperaceae. Phytochem. 1985;24(4):751-66.

110. Ghisalberti EL. Phytochemistry of the Australian rutaceae: Boronia, eriostemon and Phebalium species. Phytochem. 1998;47(2):163-76.

111. Sarker SD, Armstrong JA, Gray AI, Waterman PG. Sesquiterpenyl coumarins and geranyl benzaldehyde derivatives from the aerial parts of eriostemon myoporoides. Phytochem. 1994;37(5):1287-94.

112. Brophy JJ, Lassak EV. Steam volatile leaf oils of some Melaleuca species from Western Australia. Flavour Fragr J. 1992;7(1):27-31.

113. Davidson EW, Larsen A, Palmer CM. Potential influence of plant chemicals on infectivity of Batrachochytrium dendrobatidis. Dis Aquat Org. 2012;101(2):87-93.

114. Sargo CR, Campani G, Silva GG, Giordano RC, Da Silva AJ, Zangirolami TC, et al. Salmonella typhimurium and Escherichia coli dissimilarity: closely related bacteria with distinct metabolic profiles. Biotech Prog. 2015;31(5):1217-25. 
115. Cole E, Dos Santos R, Lacerda Júnior V, Martins J, Greco S, Cunha Neto A. Chemical composition of essential oil from ripe fruit of Schinus terebinthifolius Raddi and evaluation of its activity against wild strains of hospital origin. Braz J Microbiol. 2014;45(3):821-8.

116. Hemaiswarya S, Kruthiventi AK, Doble M. Synergism between natural products and antibiotics against infectious diseases. Phytomed. 2008;15(8): 639-52.

117. Elshafie HS, Ghanney N, Mang SM, Ferchichi A, Camele I. An in vitro attempt for controlling severe phytopathogens and human pathogens using essential oils from mediterranean plants of genus schinus. J Med Food. 2016;19(3):266-73.

118. Blanco P, Hernando-Amado S, Reales-Calderon JA, Corona F, Lira F, AlcaldeRico $\mathrm{M}$, et al. Bacterial multidrug efflux pumps: much more than antibiotic resistance determinants. Microorganisms. 2016;4(1):14.

119. Lomovskaya O, Bostian KA. Practical applications and feasibility of efflux pump inhibitors in the clinic-a vision for applied use. Biochem Pharmacol. 2006;71(7):910-8.

120. Chavez Carvajal P, Coppo E, Di Lorenzo A, Gozzini D, Bracco F, Zanoni G, et al. Chemical characterization and in vitro antibacterial activity of Myrcianthes hallii (O. berg) McVaugh (Myrtaceae), a traditional plant growing in Ecuador. Materials. 2016;9(6):454.

121. Elisha IL, Botha FS, McGaw L, Eloff JN. The antibacterial activity of extracts of nine plant species with good activity against Escherichia coli against five other bacteria and cytotoxicity of extracts. BMC Complement Altern Med. 2017;17(1):133

122. Valle DL Jr, Andrade Jl, Puzon JJM, Cabrera EC, Rivera WL. Antibacterial activities of ethanol extracts of Philippine medicinal plants against multidrug-resistant bacteria. Asian Pac J Trop Biomed. 2015;5(7):532-40.

123. Ushimaru P, Barbosa L, Fernandes A, Di Stasi L, Júnior AF. In vitro antibacterial activity of medicinal plant extracts against Escherichia coli strains from human clinical specimens and interactions with antimicrobial drugs. Nat Prod Res. 2012;26(16):1553-7.

124. Shou Q, Banbury LK, Renshaw DE, Lambley EH, Mon H, Macfarlane GA, et al. Biologically active dibenzofurans from Pilidiostigma glabrum, an endemic Australian Myrtaceae. J Nat Prod. 2012;75(9):1612-7.

125. Al Khateeb W, Hussein E, Qouta L, Alu'datt M, Al-Shara B, Abu-Zaiton A. In vitro propagation and characterization of phenolic content along with antioxidant and antimicrobial activities of Cichorium pumilum Jacq. Plant Cell Tiss Org. 2012;110(1):103-10.

126. Masondo N, Ndhlala A, Aremu A, Van Staden J, Finnie J. A comparison of the pharmacological properties of garden cultivated and muthi market-sold Bowiea volubilis. S Afr J Bot. 2013;86:135-8.

127. Ncube B, Finnie J, Van Staden J. Seasonal variation in antimicrobial and phytochemical properties of frequently used medicinal bulbous plants from South Africa. S Afr J Bot. 2011;77(2):387-96.

Ready to submit your research? Choose BMC and benefit from:

- fast, convenient online submission

- thorough peer review by experienced researchers in your field

- rapid publication on acceptance

- support for research data, including large and complex data types

- gold Open Access which fosters wider collaboration and increased citations

- maximum visibility for your research: over $100 \mathrm{M}$ website views per year

At BMC, research is always in progress.

Learn more biomedcentral.com/submissions 